\title{
DETECTION OF AN INVASIVE SPECIES ARION VULGARIS MOQUIN-TANDON, 1855 (MOLLUSCA: GASTROPODA: ARIONIDAE) IN THE REPUBLIC OF NORTH OSSETIA-ALANIA
}

\author{
EVGENIY V. SCHIKOV ${ }^{1 *}$, YURIY E. KOMAROV ${ }^{2}$ \\ ${ }^{1}$ Tver State University, Biological Faculty / Kalinina, 37-21, Lyubertsy, Moscow Region, 140002, Russia \\ (e-mail: e v schik@mail.ru) \\ ${ }^{2}$ North Ossetian State Nature Reserve / Chabakhan Basieva 3-3, Alagir, Republic of North Ossetia-Alania, \\ 363245, Russia (e-mail: borodachyu.k@mail.ru) \\ * corresponding author
}

ABSTRACT: Arion vulgaris Moquin-Tandon is a serious agricultural pest. Its rapid spread started in the middle of the twentieth century. Currently, its range covers almost all of Western Europe and it is rapidly expanding to the east. A. vulgaris has been recorded in the Baltics, Ukraine, and central Russia; it is also found in the Faroe Islands. In 2009, it was discovered in Russia in the commercial greenhouses of Tver. Now it has spread in the suburbs and Moscow. On the 6th of August 2019, a population of this species was found in the arboretum of Vladikavkaz, North Ossetia which is the first record of A. vulgaris in the Caucasus. Description of the slug's genitalia is given.

KEY WORDS: Arion vulgaris; Arionidae; adventitious species; plant pests; Caucasus fauna

\section{INTRODUCTION}

Arion vulgaris Moquin-Tandon, 1855 is a serious agricultural pest. Initially, it was believed to have originated from Spain, hence the name "Spanish slug". A. vulgaris comes from south-western Europe. In the middle of the 20th century it started spreading very rapidly. Currently, its range covers almost all of Western Europe and the slug continues to expand. A. vulgaris is now found in Belarus, the Baltic countries and Ukraine, as well as North America and even in the Faroe Islands (VAN REgTEREN AltenA 1971, LIKHAREV \& WIKTOR 1980, DAVIES 1987, RISCH \&
BACKELJAU 1989, GURAL-SVERLOVA \& GURAL 2011, PĂPUREANU et al. 2014, SLOTSBO 2014, BALASHOV 2016, ZAJĄC et al. 2017, ZEMANOVA et al. 2018, PROKOPCHIK \& RHYZHAYA 2020, REISE et al. 2020, ZEMOGLYADCHUK 2020, ARAIZA-GÓMEZ et al. 2021).

A. vulgaris was first discovered in Russia in 2009 in commercial greenhouses in Tver and then Moscow (SCHIKOV 2016). Now it has spread in Moscow and the Moscow region, where it does serious damage in the gardens. The record of A. vulgaris in North Ossetia-Alania is the first in the Caucasus.

\section{MATERIAL AND METHODS}

The material was collected by Yu. E. KOMAROV in North Ossetia on the 6th of August 2019. It included 12 specimens of $A$. vulgaris from the northern part of the Vladikavkaz's arboretum (Figs 1-2). The arbo- retum, founded in 1982, is 151 hectares in area. It is located at $780-800 \mathrm{~m}$ a.s.l., on the southern outskirts of the city at the foot of the Lysaya Mountain (KOMZHA \& POPOV 2000). 

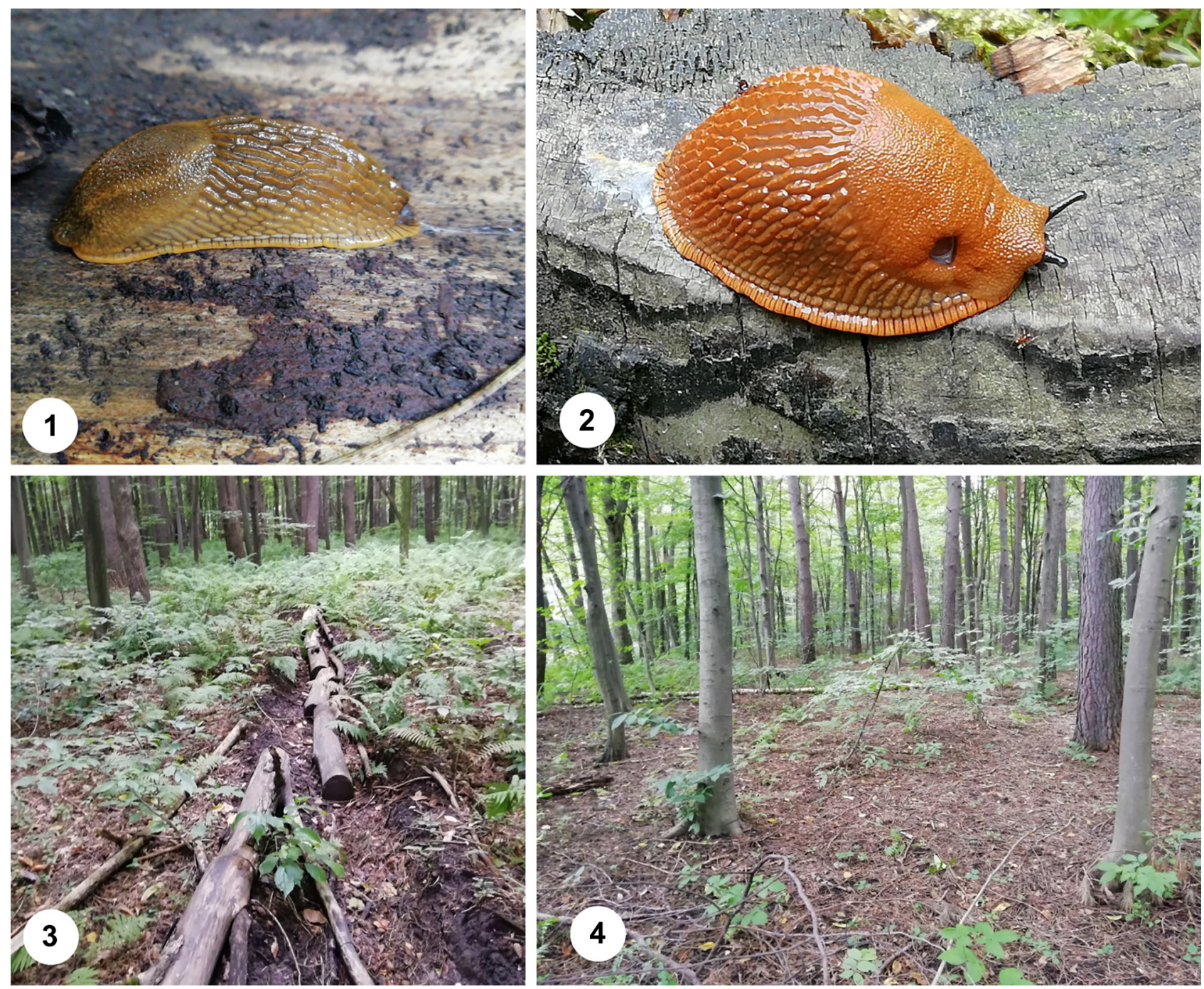

Figs 1-4. Slugs and their habitats: 1 - adult Arion vulgaris, spermatogenesis phase; 2 - contracted adult Arion vulgaris, oogenesis phase; 3, 4 - habitats of Arion vulgaris in the arboretum of Vladikavkaz

The Spanish slug occurs only in the northern part of the arboretum. A broadleaf forest grows there, which is dominated by group-planted trees: Fraxinus excelsior L., Robinia pseudoacacia L., Acer platanoides L., A. pseudoplatanus L., Aesculus hipocastanum L., Tilia cordifolia L. T. caucasica Rupr., Ulmus glabra L. Fagus orientalis Lipsky; occasionally - Pinus silvestris L. There is no shrub layer, only in some places the undergrowth of the main tree species forms underbrush. Shrubs grow on the fringes of the arboretum: Euonymus verrucosa Scop., Sambucus nigra L., Corylus avellana $\mathrm{L}$. The herb layer includes Pachyphragma macrophylla N. Busch, Carex sylvatica Huds., C. leporina L.; ferns Matteuccia strutiopteris (L.) Todaro, Athyrium filix-femina (L.) Roth, Dryopteris filix-mas (L.) Schott., and, occasionally, Oxalis acetosella L. grow in better lit or moist places. Urtica dioica L. grows along the edge of the arboretum (KOMZHA \& POPOV 2000, KOMZHA et al. 2000) (Figs 3-4). The territory of the arboretum is mowed periodically (KOMZHA et al. 2000).
There are no streams or drainage ditches in the arboretum. A village with gardens and orchards adjoins the northern part of the arboretum inhabited by the Spanish slug.

Photos of live slugs, their habitats and quantitative counts were taken by Yu. E. KOMAROV. The slugs were fixed both in the traditional way: they were placed in $70 \%$ ethanol after being left in water for 48 hours, or immediately preserved in $95 \%$ ethanol. The number of slugs per unit area of the habitat was estimated by counting at three sites, each of $1 \mathrm{~m}^{2}$.

Drawings based on photographs were done according to the original method of E. Schikov (Fig. 5), with the following protocol: 1 . Spread the genitalia horizontally and photograph them next to a ruler. 2 . On the computer, mark all the edges of the genitalia with black marks. 3. Lighten the photo so that only the black marks remain. 4. Print the image. 5. Circle all the black marks on paper. The resulting image is accurate but rough. 6 . Put a blank sheet of paper 


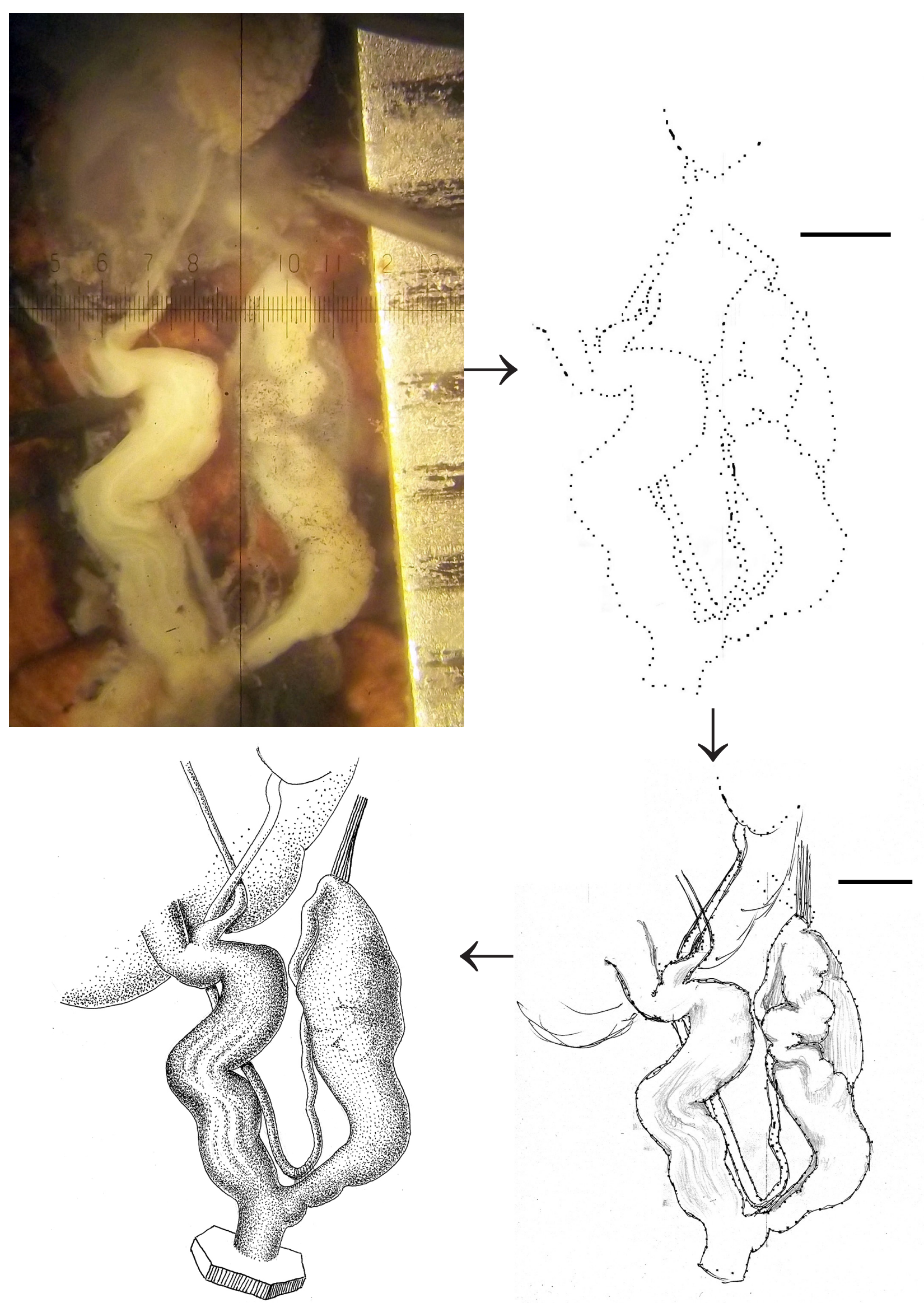

Fig. 5. Stages of drawing genitalia. For explanations see Material and Methods. Scale bars $20 \mathrm{~mm}$ 
on the resulting image and, using transmitted light, copy the draft image onto a blank sheet to remove all rough lines. 7 . Draw shadows and create a volumetric image. The technique is very simple and excludes errors in drawing contours. The ruler in the figure makes it possible to take accurate measurements of individual parts of the genitalia.

The definition of the proximal and distal parts of the genitalia adopted here assumes that the hermaphrodite gland is the beginning of the reproductive system. The proximal part of the organ is closer to the gland, and the distal - farther from the gland. In relation to the hermaphrodite gland, we consider the proximal part to be the part opposite to the point where the hermaphrodite duct leaves the gland.

Abbreviations: A - atrium, DH - hermaphrodite duct, E - epiphallus, F - fold within atrium, connected with ligula, GA - albumen gland, GH - hermaphrodite gland, L - ligula, OV - oviduct, OVEX - distal expanded part of oviduct, $\mathrm{R}$ - retractor, SP - spermatheca, SPD - spermatheca duct, SPOV - spermoviductus, VD - vas deferens.

\section{RESULTS}

The slugs were found under fallen and felled maple trees and among fallen and rotting foliage (Figs $1-4)$. The number of slugs in the habitat was 2.6 specimens $/ \mathrm{m}^{2}$.

The structure of the genitalia is consistent with the previously published descriptions (LIKHAREV \& WIKTOR 1980). Dissections showed that both adults and juveniles of different ages were simultaneously present in the population. The juveniles have dark stripes on both margins of the back and mantle. With maturity the slugs first enter the phase of spermatogenesis (Figs 6-7). In this period, the dark stripes still remain (Fig. 1) and do not disappear after fixation with ethanol. With further growth, the animals enter the phase of oogenesis, the stripes disappear and the slugs become monochromatic when viewed from above (Fig. 2).

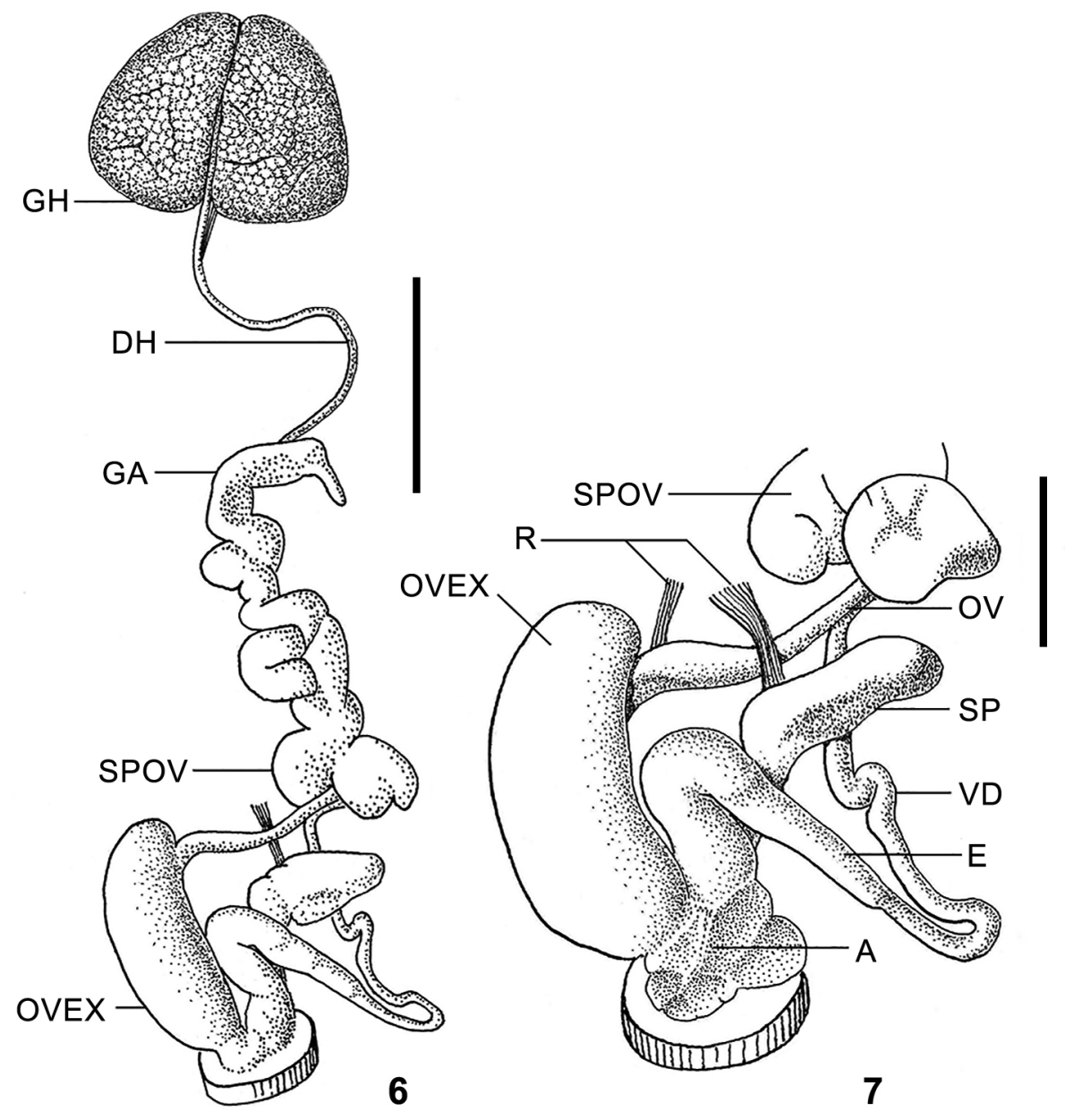

Figs 6-7. Genitalia in the phase of spermatogenesis: 6 - general view, scale bar $10 \mathrm{~mm}$; 7 - distal part. Scale bar $5 \mathrm{~mm}$. For lettering see Material and methods 

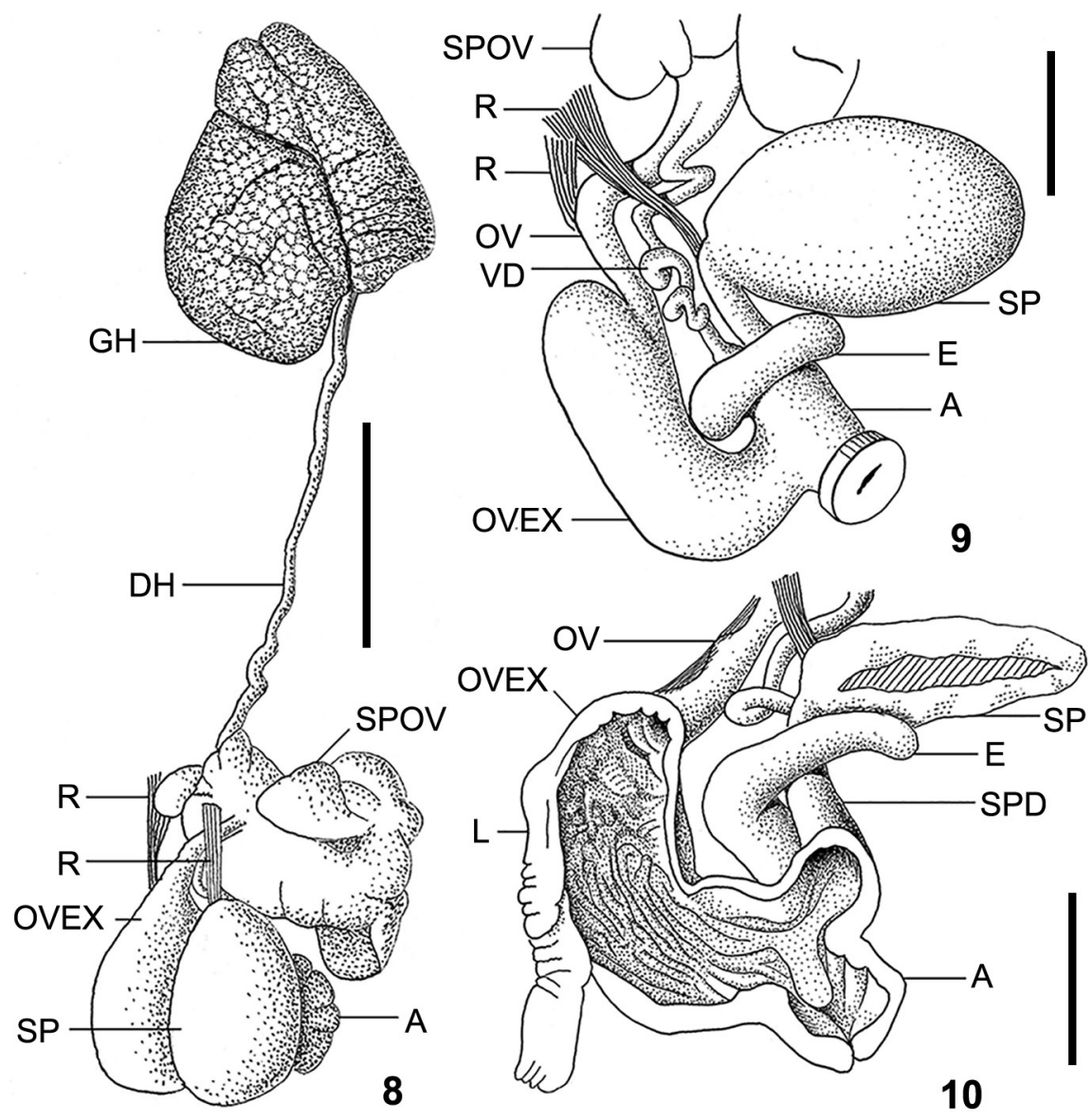

Figs 8-10. Genitalia in the phase of oogenesis: 8 - general view, scale $10 \mathrm{~mm}$; 9 - distal part of the genitalia; 10 - same individual. Spermatheca opened, shifted to the right, its contents not shown; distal part of oviduct and atrium opened, ligula bent back. Scale bars $5 \mathrm{~mm}$. For lettering see Material and methods
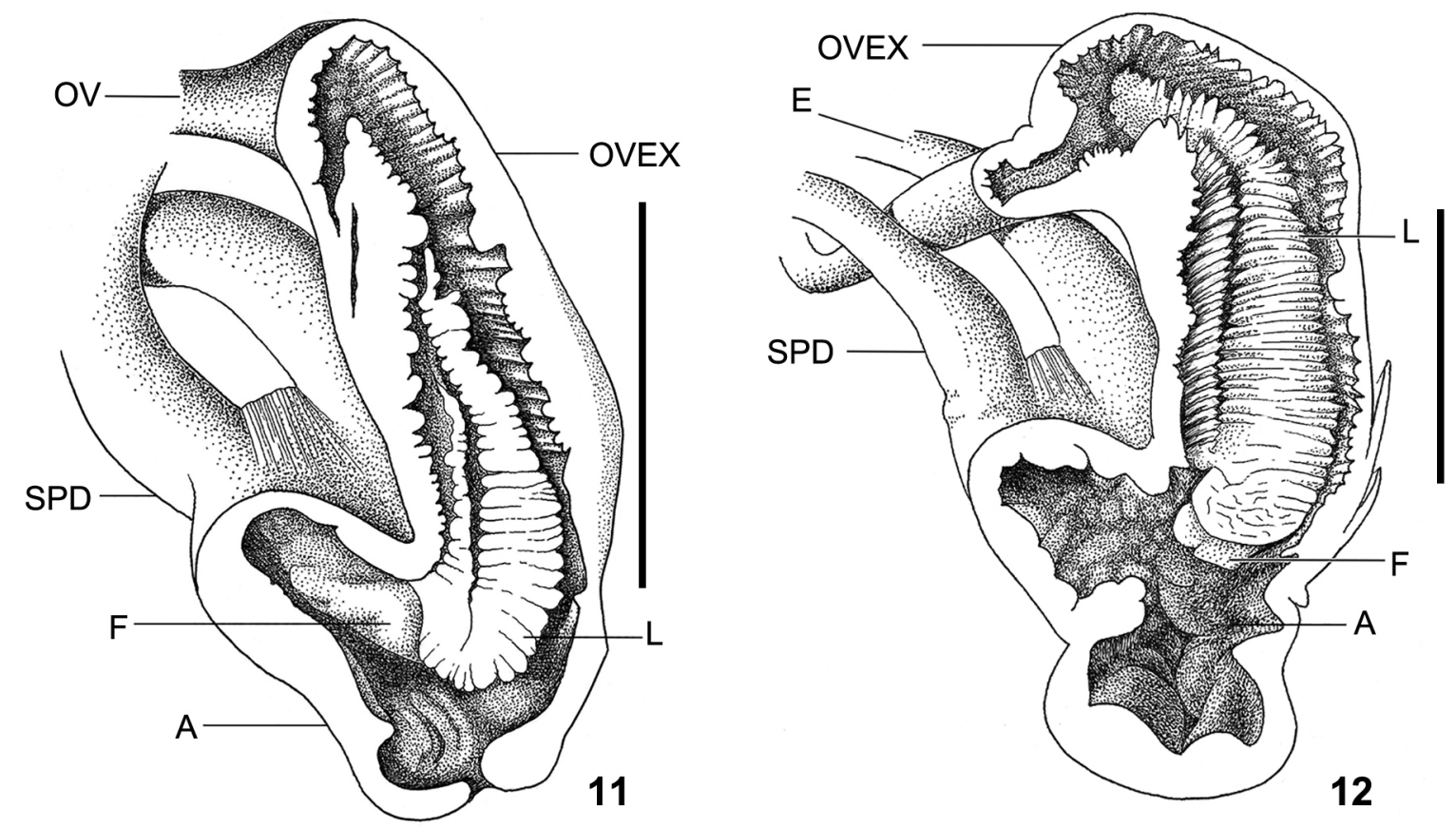

Figs 11-12. Distal parts of genitalia of two individuals in the phase of spermatogenesis. Atrium and distal portion of oviduct longitudinally cut. Scale bars $5 \mathrm{~mm}$. For lettering see Material and methods 
The hermaphrodite gland is large and consists of two parts. They are almost symmetrical sometimes (Fig. 6), but usually - asymmetrical (Fig. 8). Often, both its parts are connected proximally. Some acini of the hermaphrodite gland are rounded. Their thin ducts merge into a common duct in each part of the gland. Both common ducts are connected inside the gland into the hermaphrodite duct which, with mild bends, leads to the albumen gland (Figs $6 \& 8$ ). The albumen gland is small and elongated. The spermoviduct forms several irregular coils (Fig. 6) and in situ is compressed into a lump (Fig. 8).

The oviduct is divided into two parts: a narrow proximal part and a strongly expanded distal part. The inner surface of the expanded part is completely covered by thin, slightly bent longitudinal folds (Fig. 10). There is a ligula inside that part. It is formed by long folds, which reach the atrium and are connected by their distal ends. The atrial fold is separated from the ligula. The ligula and atrium folds differ in

\section{DISCUSSION}

KERNEY et al. (1983), BACKELJAU \& DE BRUYN (1990), and other malacologists from Western Europe indicate that adult $A$. vulgaris have stripes on their bodies. LIKHAREV \& WIKTOR (1980), WIKTOR (2004) and others claim that mature A. vulgaris in Poland do not have stripes. According to our observations, in the Moscow and Tver populations stripes appear only in juveniles. Moreover, as the slugs grow, they first become monochromatic, and only then the genitalia become fully mature. The presence of stripes in sexually mature A. vulgaris from North Ossetia is noteworthy, but the small number of studied specimens does not permit definite conclusions. Examination of the genitalia of the scanty material indicates a considerable variation, but the material is not sufficient for a proper analysis.

The spread of $A$. vulgaris is anthropogenic. During landscaping of cities, villages and summer cottages, seedlings and sprouts are often bought, together with soil which contains the eggs of the slug. Then, the process becomes rapid, considering that the Spanish slug is hermaphroditic and, as self-fertilisation sometimes occurs, even relocation of a single indi- their surface structure. The ligula folds are covered by thin transverse folds, and the surface of the atrium fold is smooth. The transverse folds of the ligula are blunt (Fig. 11) or sharp (Fig. 12). The distal end of the ligula reaches the atrium (Fig. 12), but may also considerably extend into it (Fig. 11). The atrial fold, which accretes to the ligula, is either very short (Fig. 9) or long, extending into the proximal part of the spermatheca duct (Fig. 11).

A long and strongly convoluted vas deferens passes into a gradually expanding epiphallus. It encircles the spermatheca duct and opens into the atrium between the spermatheca duct and the oviduct (Figs 7, $9 \& 10$ ). The spermatheca is distended (Figs 6-7). In the phase of oogenesis, filled with sperm, it is so swollen that it covers almost all the distal parts of the genitalia (Figs 9-10). The atrium is short but wide. Its walls have a variety of muscular thickenings (Figs 10-12).

vidual may aid further spread of the species (GURALSVERLOVA \& GURAL 2011).

The appearance of $A$. vulgaris in North Ossetia may imply losses in agricultural production. The slugs eat more than 100 plant species and are capable of doing serious damage in gardens and fields (ProschWITZ \& WINGE 1994, KOZŁOWSKI \& KOZŁOWSKA 2004, KoZŁOWSKI 2005, 2007, and others). The neighbourhood of the arboretum and the village with gardens and orchards creates favourable conditions for penetration of $A$. vulgaris into the village.

\section{ACKNOWLEDGEMENTS}

We sincerely thank Professor A. A. NOTOV (Tver State University) for his help with botanical terminology. We are especially grateful to our friend and colleague D. M. PALATOV (Moscow State University) for his help in preparing photographs and drawings. Special thanks go to HEIKE REISE and JOHN M. C. HUTCHINSON (Germany) for their valuable critical comments.

\section{REFERENCES}

ARAIZA-GÓmEZ V., NARANJO-GARcíA E., ZÚÑIGA G. 2021. Occurrence in Mexico of two European invasive slug species: Arion vulgaris Moquin-Tandon, 1855 and Arion intermedius (Norman, 1852). BioInvasions Records 10: 10-20.

https://doi.org/10.3391/bir.2021.10.1.02
BACKELJAU T., DE BRUYN L. 1990. On the infrageneric systematics of the genus Arion Férussac, 1819 (Mollusca, Pulmonata). Bulletin de l'Institut Royal des Sciences Naturelles de Belgique 60: 35-68.

BALASHOV I. A. 2016. Mollyuski. Stebelchatoglazye. Fauna Ukrainy. Naukova Dumka, Kiev. 
DAVIES S. M. 1987. Arion flagellus Collinge and A. lusitanicus Mabille in the British Isles: a morphological, biological and taxonomic investigation. Journal of Conchology 32: 339-354.

GURAL-SVERLOVAN. V., GURAL R. I. 2011. Morfologicheskiye, anatomicheskiye i povedencheskiye kharakteristiki slizney kompleksa Arion lusitanicus s. 1. (Arionidae) na zapade Ukrainy. Ruthenica 21: 97-111.

Kerney M. P., Cameron R. A. D., Jungbluth J. H. 1983 Die Landschnecken Nord- und Mitteleuropas. Parey, Hamburg-Berlin.

Komzha A. L., Georgiev A. V., Popov K. P. 2000 Kultiviruyemye drevesno-kustarnikovye vidy yestestvennoy flory i introdutsenty. In: VAGIN V. S., KOMZHA A. L., POPOV K. P. (eds). Rastitelnyi mir. "ProyektPress», Vladikavkaz, pp. 207-237.

KomZHA A. L., POPOV K. P. 2000. Ocherk istorii introduktsii derevyev i kustarnikov. In: VAGIN V. S., KOMZHA A. L., POPOV K. P. (eds). Rastitelnyi mir. "ProyektPress», Vladikavkaz, pp. 199-206.

KOZŁOWSKI J. 2005. Host plants and harmfulness of the Arion lusitanicus Mabille, 1868 slug. Journal of Plant Protection Research 45: 221-233.

KoZŁOWSKI J. 2007. The distribution, biology, population dynamics and harmfulness of Arion lusitanicus Mabille, 1868 (Gastropoda: Pulmonata: Arionidae) in Poland. Journal of Plant Protection Research 47: 219-230.

KozŁOWSKI J., KozŁowsKA M. 2004. Food preferences of Deroceras reticulatum, Arion lusitanicus and Arion rufus for various medicinal herbs and oilseed rape. Journal of Plant Protection Research 44: 239-250.

LIKHAREV I. M., WIKTOR A. Y. 1980. Slizni fauny SSSR i sopredelnykh stran (Gastropoda terrestria nuda). Fauna SSSR. Mollyuski. T. III. no. 5. Nauka, Leningrad.

PĂPUREANU A.-M., ReISE H., VARGA A. 2014. First records of the invasive slug Arion lusitanicus auct. non Mabille (Gastropoda: Pulmonata: Arionidae) in Romania. Malacologica Bohemoslovaca 13: 6-11.

PROKOPCHIK A. S., RHYZHAYA A. V. 2020. Invazivnyi slizen Arion lusitanicus v gorodskoy obshchine Grodno (Respublika Belarus). Ekologicheskaya kul'tura i okhrana okruzhayushchey sredy: III Dorofeyevskiye chteniya: Materialy mezhdunarodnoy nauchno-prakticheskoy konferentsii. Vitebsk, 28-29 oktyabrya 2020 g. Vitebskiy gosudarstvennyy universitet imeni P. M. Masherova, Vitebsk: 159-161.
Proschwitz T. VON, WINGE K. B. 1994. Iberia skogsnegl - en art pä spredning i Norge (Arion lusitanicus Mabille en anthropochorous slug spreading in Norway). Fauna 47: 195-300.

RISCH P., BACKELJAU T. 1989. On the occurrence of Arion lusitanicus Mabille, 1868 in Belgium (Mollusca: Pulmonata). Annales de la Société Royale Zoologique de Belgique 118: 25-38.

Regteren Altena C. O. VAN 1971. Neue Fundorte von Arion lusitanicus Mabille. Archiv für Molluskenkunde 101: 183-185.

Reise H., SCHWARZER A.-K., HutChinson J. M. C., SCHLITT B. 2020. Genital morphology differentiates three subspecies of the terrestrial slug Arion ater (Linnæus, 1758) s. 1 . and reveals a continuum of intermediates with the invasive $A$. vulgaris Moquin-Tandon, 1855. Folia Malacologica 28: 1-34. https://doi.org/10.12657/folmal.028.001

SCHIKOV E. V. 2016. Adventivnye vidy nazemnoy malakofauny tsentra Russkoy ravniny. Ruthenica 26: 153-164.

SLOTSBO S. 2014. NOBANIS - Invasive alien species fact sheet - Arion lusitanicus. Online Database of the European Network on Invasive Alien Species NOBANIS. Available online at www.nobanis.org (accessed 20 December 2020).

WiKTOR A. 2004. Ślimaki lądowe Polski. Mantis, Olsztyn.

ZAJAC K., GAWEŁ M., FILIPIAK A., KRAMARZ P. 2017. Arion vulgaris Moquin-Tandon, 1855 - the aetiology of an invasive species. Folia Malacologica 25: 81-93. https://doi.org/10.12657/folmal.025.008

ZEMANOVA M. A., BroennimanN O., GUISAN A., KNOP E., HECKEL G. 2018. Slimy invasion: climatic niche and current and future biogeography of Arion slug invaders. Diversity and Distributions 24: 1627-1640. https://doi.org/10.1111/ddi.12789

ZEMOGLYADCHUK K. V. 2020. Cuzherodnye vidy nazemnykh mollyuskov (Mollusca: Gastropoda: Stylommatophora) $\mathrm{v}$ faune Belarusi. Vestnik BarGU. Seriya: Biologicheskiye nauki. Selskhokhozyaystvennye nauki 8: 34-45.

Received: February 2nd, 2021

Revised: July 25th, 2021

Accepted: October 31st, 2021

Published on-line: December 6th, 2021 